\title{
Intellectual capital and business performance in the pharmaceutical sector of Jordan
}

Abdel-Aziz Ahmad Sharabati and Shawqi Naji Jawad

College of Administrative and Financial Studies, Amman Arab University, Amman, Jordan, and

Nick Bontis

DeGroote School of Business, McMaster University, Hamilton, Canada

\begin{abstract}
Purpose - The purpose of this study is to empirically test the relationship between intellectual capital (i.e. human capital, structural capital, relational capital) and business performance within the pharmaceutical sector of Jordan.

Design/methodology/approach - A valid research instrument was utilized to conduct a survey of 132 top- and middle-level managers from all 15 members of the Jordanian Association of Pharmaceutical Manufacturers.

Findings - A correlation and path analysis were conducted to ascertain the validity of the measures and models. Statistical support was found for the hypothesized relationships.

Research limitations/implications - The findings offer valuable insights on the generalizability of intellectual capital in a novel research setting.

Practical implications - Intellectual capital measurement is of primary interest for senior executives of pharmaceutical firms in Jordan.

Originality/value - The research reported is among only a few to investigate the issue of intellectual capital in Egypt and the first to study pharmaceutical firms.
\end{abstract}

Keywords Business performance, Intellectual capital, Human capital, Pharmaceuticals industry, Manufacturing systems, Jordan

Paper type Research paper

\section{Introduction}

Although intellectual capital may be a source of competitive advantage, generally speaking, most organizations do not understand its nature and value (Collis, 1996). Nevertheless, one of the first firms ever to report on their invisible assets was Skandia (Bontis, 1998). The field has since exploded with dozens of dedicated publications and academic researchers (see Serenko and Bontis, 2004, 2009; Bontis and Serenko, 2009 for comprehensive reviews and journal rankings).

The multidisciplinary nature of intellectual capital lends itself to both a richness of perspective as well as a difficulty for valuation (Bontis et al., 1999) and relevance (Booker et al., 2008). Facing intense globalized competition, there is a widespread recognition that intellectual capital is a critical force that drives economic growth (Huang and Liu, 2005).

One particular industry that is considered knowledge-intensive and a source of great intellectual capital is the pharmaceutical industry (Daum, 2005). This industry is research-intensive (DeVol et al., 2004), highly innovative (Chen, 2004), well balanced in

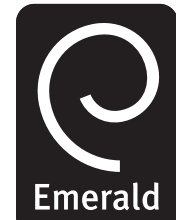

Management Decision Vol. 48 No. 1,2010 pp. $105-131$ (c) Emerald Group Publishing Limited 0025-1747 DOI 10.1108/00251741011014481 
$\mathrm{MD}$

48,1

106 its use of human intervention and technology (Hermans, 2004), and to a large extent dependent on its intellectual capital for a source of renewal (Zucker et al., 1994). Ultimately, it is a great choice for analyzing intellectual capital components (Bollen et al., 2005).

Much of the extant research on intellectual capital has focused on the developed world - specifically within Anglophonic and Scandinavian nations. However, this phenomenon has global appeal as evidenced in studies within Mexico (Trevinyo-Rodriguez and Bontis, 2007), Portugal (Cabrita et al., 2007; Cabrita and Bontis, 2008), Ireland (O’Regan et al., 2001; 2005), Germany (Kristandl and Bontis, 2007), Australia (Bontis and Girardi, 2000), Malaysia (Bontis et al., 2000), Egypt (Seleim et al., 2004, 2007) and others. Bontis (2004) points out that there is also great interest in intellectual capital development in the Arab region as well.

The pharmaceutical industry is an important and crucial sector in the Jordanian economy. Economically speaking, this sector represents the second largest in terms of exports after the phosphate industry (Hijjawi, 2006). The major difference between the phosphate industry and pharmaceutical industry is that Jordan sells phosphate as a raw material, while in the pharmaceutical industry it imports raw materials and processes them into finished products to be exported. The process of commercializing pharmaceuticals is very knowledge-intensive and thus provides a fruitful setting for intellectual capital assessment.

The research setting for this particular study is unique because the concept of intellectual capital is not well known to most managers in the pharmaceutical industry in Jordan. Therefore, the expected contributions of this research are as follows:

(1) Whereas intellectual capital measurement studies often focus on accounting measures and financial calculations (e.g., VAIC), these require publicly traded companies whose results are fully disclosed and available. This particular study encompasses both public and private pharmaceutical companies.

(2) This study represents one of only a handful in the extant literature to focus on the Arab region and the first one to focus on measuring intellectual capital development in this particular sector in Jordan. It thus offers a novel perspective.

(3) This research is an extension of the study conducted by Seleim et al. (2004) which focused on software companies in Egypt. The results here may allow for generalizability across different countries and industries.

(4) A large proportion of intellectual capital measurement studies examine first-level constructs (e.g., human capital, structural capital, and relational capital). This particular study digs deeper by examining sup-phenomena within each of the first-level constructs. It thus offers a more granular perspective of intellectual capital measurement.

(5) PLS-Graph software is used as the structural equation modelling technique in this research study. This same software has been used in many previous studies, which allows for the direct comparison of results to determine potential differences attributed to the novel context of this particular research setting.

Ultimately, the purpose of this research study is to measure the effect of intellectual capital elements on the business performance of Jordanian pharmaceutical firms. 


\section{Literature review}

Much of the literature on intellectual capital stems from an accounting and financial perspective (Bontis, 2001). Many of these researchers are interested in answering the following two questions:

(1) What is causing firms to be worth so much more than their book value?

(2) What specifically is in this intangible asset?

Stewart (1997) defines intellectual capital as the intellectual material that has been formalized, captured, and leveraged to create wealth by producing a higher-valued asset. Following the work of Edvinsson and Malone (1997), Sveiby (1997), Roos et al. (1997), Bontis (1999), O'Donnell et al. (2004, 2006), Sällebrant et al. (2007), Curado and Bontis (2007) among others, intellectual capital is defined as encompassing:

- human capital;

- structural capital; and

- relational capital.

These sub-phenomena encompass the intelligence found in human beings, organizational routines and network relationships respectively. This field typically looks at organizational knowledge as a static asset in an organization - a so-called stock. This concerns many theorists who are also interested in the flow of knowledge. Furthermore, intellectual capital research does not cater to changes in cognition or behaviour of individuals which is necessary for learning and improvement. Naturally, the field of knowledge management dovetails nicely as it focuses on the flow of information (Curado and Bontis, 2006).

To understand the intellectual capital imbedded in an organization requires organizational members to assess their core competencies; those areas where they can achieve or have achieved "best-in-the-world" status. The intellectual capital of an organization represents the wealth of ideas and ability to innovate which will determine the future of the organization. Why have management accountants and financial analysts avoided this area until recently? The most obvious answer is that intellectual capital is not only difficult to measure but also difficult to evaluate. In the past, accountants have assumed a position which either ignores the problems or writes them off as impossible to solve (Luscombe, 1993; Bontis, 2003). It is important to realize that intellectual capital is real and provides value (Andreou and Bontis, 2007). One need only look at the hackneyed example of Microsoft whose accounting book value is significantly less than its market value based on share price to see that there must be some explanation of this "excess" market valuation. Arguably this "excess" is the market valuation of the intellectual capital stocks and organizational learning flows of the company.

\section{Research model}

Figure 1 outlines the proposed research model of this study. Essentially, this model posits that there is a direct and positive association between intellectual capital and business performance (Stewart, 1997). By subdividing the higher-order construct of intellectual capital into its three components human capital, structural capital and relational capital; the first proposed hypothesis is as follows:
IC and business performance 
$\mathrm{MD}$

48,1

108

Figure 1.

Conceptual model

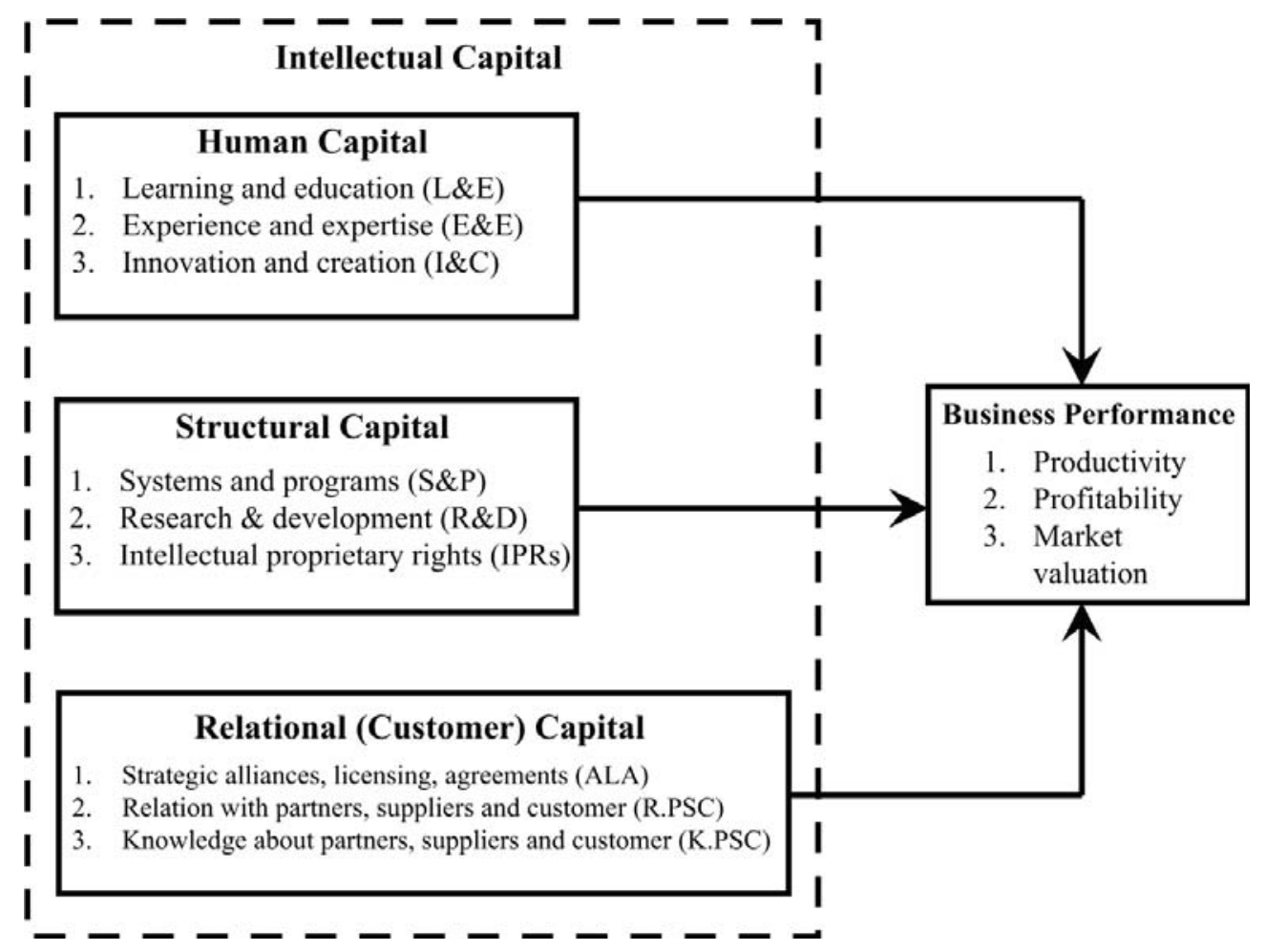

H1. Intellectual capital is positively influenced by human capital, structural capital and relational capital.

EQ1. Intellectual capital $=\beta_{0}+\beta_{1}(\mathrm{HC})+\beta_{2}(\mathrm{SC})+\beta_{3}(\mathrm{RC})$

where: $\mathrm{HC}=$ human capital, $\mathrm{SC}=$ structural capital, $\mathrm{RC}=$ relational capital $\beta_{1}, \beta_{2}, \beta_{3}$ are expected to be $>0$

By further subdividing the three primary constructs of intellectual capital, the second through fourth hypotheses posit the positive influence that these summative sub-components possess. First human capital is defined as the accumulated value of investments in the employee's training and competence (Edvinsson and Malone, 1997). It also contains the competence, skills, and intellectual agility of the individual employees (Roos et al., 1997). Zambon (2002) adds that human capital includes the collective knowledge, creativity and innovativeness of people within an organization. Therefore, the following hypothesis is proposed:

H2. Human capital is positively influenced by innovation \& creation, learning \& education, and experience and expertise.

EQ2. Human capital $=\beta_{0}+\beta_{1}(\mathrm{I} \& \mathrm{C})+\beta_{2}(\mathrm{~L} \& \mathrm{E})+\beta_{3}(\mathrm{E} \& \mathrm{E})$

where: $\mathrm{I} \& \mathrm{C}=$ innovation $\&$ creation, $\mathrm{L} \& \mathrm{E}=$ learning $\&$ education

$\mathrm{E} \& \mathrm{E}=$ experience and expertise

$\beta_{1}, \beta_{2}, \beta_{3}$ are expected to be $>0$

Structural capital consists of the non-human storehouses of knowledge in an organization that are embedded in systems, databases and programs (Edvinsson and 
Malone, 1997). Unlike human capital, structural capital is an intangible asset that can be traded, reproduced and shared within the firm (Zambon, 2002). In fact, certain structural capital elements can be legally protected in the form of patents and trademarks as a result of investment in research and development (Roos et al., 1997). However, Choo and Bontis (2002) argue that intellectual property and intellectual capital are mutually exclusive. Therefore, the following hypothesis is proposed:

H3. Structural capital is positively influenced by systems \& programs, research \& development, and inversely influenced by intellectual property rights.

EQ3. Structural Capital $=\beta_{0}+\beta_{1}(\mathrm{~S} \& \mathrm{P})+\beta_{2}(\mathrm{R} \& \mathrm{D})-\beta_{3}(\mathrm{IPR})$.

where: $\mathrm{S} \& \mathrm{P}=$ systems $\&$ programs, $\mathrm{R} \& \mathrm{D}=$ research $\&$ development, IPR $=$ intellectual property rights

$\beta_{1}, \beta_{2}$ are expected to be $>0, \beta_{3}$ is expected to be $<0$

Relational capital represents all the knowledge embedded in relationships with external parties such as customers, suppliers, partners and other external stakeholders (Roos et al., 1997). However Roos and his colleagues also describe an important distinction between the actual relationship between these stakeholders and the knowledge about these stakeholders. Zambon (2002) further extends this notion to include formal alliances, licensing and partner agreements as evidence of these external relationships. Therefore, the following hypothesis is proposed:

H4. Relational capital is positively influenced by relations and knowledge about partners, suppliers and customers, in addition to alliances, licensing and agreements.

EQ4. Relational capital $=0.548+0.622($ R.PSC) $+0.184($ K.PSC) $+0.016($ ALA)

where: R.PSC $=$ relations with partners, suppliers and customers

K.PSC $=$ knowledge about partners, suppliers and customers

$\mathrm{ALA}=$ alliances, licensing and agreements

\section{Study design and methodology}

There were 15 organizations that were registered in the Jordanian Association of Pharmaceutical Manufacturers (JAPM) in 2007. The entire population was chosen to explore the topic of intellectual capital, thus negating any need for sampling. The survey unit of analysis was composed of all top and middle managers drawn from the JAPM population. Financial information was also collected from annual reports, journals, books, and trade magazines. Primary information was also collected from expert interviews, and a pilot study conducted by the research team.

The use of perceptual measures in intellectual capital research has been studied extensively by Kannan and Aulbur (2004). They argue that perceptual measures are often used to examine organizational factors that contribute to employee performance, human capital development and organizational performance. By analyzing over 100 research papers in the field of intellectual capital, Kannan and Aulbur (2004) determined that perceptual measures were among the most often used measurement techniques. Although objective measures are often found to be less susceptible to respondent bias, there is evidence that shows that both perceptual and objective measures of
IC and business performance 
$\mathrm{MD}$

48,1

110 knowledge-based assets are often congruent. In fact the use of perceptual measures for both exogenous and endogenous constructs would tend to balance out any over-inflated response bias. Given that intangible assets are difficult to measure objectively, it is common to find the use of proxy metrics and perceptual measures (Kannan and Aulbur, 2004). In a study of intellectual capital development and its link to performance in the mutual fund industry (Bontis et al., 2002), perceptual measures (i.e. survey items) and objective metrics (i.e. $\mathrm{ROR}=$ profit divided by revenue) of performance were found to have a significantly positive association $(r=0.371, p<0.01)$.

The survey instrument was based on Bontis' intellectual capital questionnaire (Bontis, 1998). Intellectual capital was sub-divided into three elements: human capital, structural capital and relational capital. Each sub-construct was operationalized with ten items that measured employees' perception of that variable. The dependent variable in the study was business performance which was measured using ten items. All items were measured with a five-point Likert-type scale.

The questionnaire was validated through expert interviews and a panel of judges. Interviews with ten experts were conducted to collect information about intellectual capital measurement tools, models and JAPM organizations' profiles. To finalize the items, the research team conducted two rounds of review with a panel of judges: the first round was with 18 academics and professionals from different Jordanian universities and pharmaceutical organizations. The second round was conducted with language professionals who were employed to revise the study instrument to ensure the use of clear language. Finally, one respondent from each of the 15 JAPM organizations was invited to participate in the pilot study. The initial results were used to test and evaluate the normality, reliability and validity of the survey instrument.

Surveys were mailed to 200 top and middle-level managers within the 15 JAPM firms. Of those, 140 were returned for a response rate of 70 percent. This relatively high response rate is attributable to the explicit support received from the head of JAPM which represents the total sample of organizations targeted. The actual number of surveys used in the analysis was 132 since eight surveys were incomplete.

\section{Results}

In order to test for the normal distribution of response data, a Kolmogorov-Smirnov (K-S) test for all dependent and independent variables was conducted. All of the items were confirmed to be normally distributed. Cronbach's alpha was used to test the reliability of the measures. For the pilot study, Cronbach's alpha results ranged between 0.75 and 0.95 for each construct which is acceptable. The Cronbach's alpha results for the actual study ranged between 0.78 and 0.90 . These values are in line with the results of Bollen et al. (2005), Bontis (1998), Miller et al.(1999), Moslehi et al.(2006) and Bin Ismail (2005).

Two methods were used to confirm validity. First, face validity was tested by interviewing the experts and panel of judges during the test pilot phase. Second, factor analysis (i.e. Pearson's principal component analysis) was conducted with and without rotation (i.e. Varimax rotation with Kaiser normalization). All variable and sub-variable items were confirmed valid since their factor loading values were more than 0.4. This result mirrors previous studies conducted by Bontis (1998), Bollen et al.(2005) and Bin Ismail (2005).

Pearson's bi-variate correlation coefficient was used to test the relationship between independent and dependent variables. The result showed that the intellectual capital 
variables and sub-variables had a substantive and significant relationship with business performance. An ANOVA test was then used to analyze respondents' characteristics related to gender, age, education, experience, department and sector. Before conducting multiple regression analysis, a test of multi-collinearity using the VIF (variance inflation factor) was also conducted.

Finally, Partial Least Squares (PLS-Graph v. 3.00) was used to test the conceptual model and relationships among independent variables and the dependent variable. PLS is a structural equation modeling technique typically chosen for handling relatively small data samples. It as been used as a research tool in a variety of research settings such as global strategy, risk-return outcomes, geographic scope and in intellectual capital research (Bontis and Serenko, 2009). Although not so well-known a modeling technique as LISREL, for instance, PLS has as its primary objective the minimisation of error (Hulland, 1999). The degree to which any particular PLS model accomplishes this objective can be determined by examining the $R$-squared values for the dependent (endogenous) constants. Unlike LISREL, PLS does not report fit indices but is used to examine the validity of beta path values and the explanatory power of the overall model ( $R$-squared).

Common method bias is of particular concern when survey respondents are asked to fill out items that tap into both independent and dependent variables. There are two tests that may be utilized to conduct a test of common method bias: Harman's one-factor test (Podsakoff and Organ, 1986) and a fully saturated causal model (Williams et al., 2003). To perform Harman's single-factor test, all variables - both dependent and independent - are entered into the model. The results of an un-rotated solution should are analyzed to determine the number of actual factors that emerge. Common method bias is present if a single or general factor appears that accounts for the majority of variables. This was not the case in this study as a one-factor model of the un-rotated solution explained only 27.1 percent of variance. A fully saturated model was also developed in which all indicators are linked to all constructs. The results of this test also show that common method bias was not present because item loadings were generally found to be statistically insignificant with unrelated constructs.

The starting-point for evaluating the validity of the survey was Bontis' (1998) instrument which originally contained ten items per construct. However, many of these items failed the proper psychometric evaluation benchmarks. This can be attributable to two reasons:

(1) Bontis' (1998) original research setting was financial services firms in Canada and the present research context is entirely different; and

(2) there may have been some slight meaning lost in translation from English to Arabic.

The remaining items selected in this study were ones that past tests for reliability, composite validity and discriminant validity (Fornell and Larcker, 1981).

Table I depicts the mean scores of each variable and its corresponding construct. Generally speaking, all items scored in the affirmative $(1=$ strongly disagree, $5=$ strongly agree, with 3 the mid-point) with mean values greater than 3.0. The only item below the mid-point was the use of intellectual property at 2.80 . These affirmative results were contrasted with previous studies conducted by Seleim et al. (2007), Miller et al. (1999), Sofian et al. (2004), Bin Ismail (2005), Salleh and Salamat (2007), Moslehi

\section{$\mathrm{IC}$ and business performance}


$\mathrm{MD}$

48,1

112
Table I.

Statistical results of summary variables

\begin{tabular}{lrrr}
\hline & & & \\
& Mean & Std. dev. & $t$-value \\
\hline Intellectual capital variables & & & \\
Learning and education & 3.58 & 0.563 & 11.768 \\
Experience and expertise & 3.45 & 0.525 & 9.906 \\
Innovation and creation & 3.27 & 0.642 & 4.880 \\
Human capital & 3.43 & 0.520 & 9.589 \\
Systems and programs & 3.17 & 0.688 & 2.897 \\
Research \& development & 3.20 & 0.809 & 2.905 \\
Intellectual property rights & 2.80 & 0.910 & -2.544 \\
Structural capital & 3.06 & 0.654 & 1.034 \\
Alliances, licensing and agreements & 3.39 & 0.752 & 5.993 \\
Relationship with partners, suppliers and customers & 3.59 & 0.612 & 11.136 \\
Knowledge about partners, suppliers and customers & 3.37 & 0.622 & 6.870 \\
Relational capital & 3.45 & 0.550 & 9.447 \\
Intellectual capital & 3.32 & 0.510 & 7.095 \\
Business performance variables & & & \\
Industry leadership & 3.48 & 0.886 & 6.186 \\
Future outlook & 3.95 & 0.927 & 11.734 \\
Overall response to competition & 3.39 & 0.889 & 5.092 \\
Success rate in new product launches & 3.30 & 0.931 & 3.647 \\
Overall business performance \& success & 3.54 & 0.833 & 7.422 \\
Employee productivity & 3.37 & 0.785 & 5.430 \\
Process (transaction) productivity & 3.38 & 0.737 & 5.909 \\
Sales growth & 3.39 & 0.946 & 4.691 \\
Profit growth & 3.45 & 0.944 & 5.442 \\
Company market valuation (stock value) & 3.33 & 0.904 & 4.141 \\
& & &
\end{tabular}

et al. (2006), Berglund et al. (2002), Lim (2002), Kukko et al. (2003), Bollen et al. (2005), Bontis (1998), Bontis et al. (2000), Bontis and Fitz-enz (2002), Firer and Stainbank (2003), Tomer (2005), Xiaojun (2004), Seng et al. (2004), Westhuizen (2005), Chen (2004), Gallego and Rodriguez (2005), Heimeriks and Duysters (2003), and Cuganesan (2005).

Table II contrasts the results of this particular study with the variable mean scores of previous intellectual capital studies. A quick scan of these results clearly indicates a consistency of values for intellectual capital scores regardless of sectoral or country context. This bodes well for the generalizability of results. Table III represents a correlation matrix across all variables with all values being statistically significant $(p<0.01)$. The explanatory power $\left(R^{2}\right)$ of each construct within its nomological network is presented in Table IV which contrasts values from previous studies. Once again we see generalizability across various settings. Table V depicts the correlations among constructs and contrasts these values with previous studies.

The results related to path analysis showed that the three sub-constructs of intellectual capital together have a positive and substantive association with business performance which was on par with previous studies. The relationship between the dependent variable of intellectual capital and its sub-constructs derived by this model can be expressed with the following equation:

EQ1. Intellectual capital $=0.259+0.411(\mathrm{HC})+0.054(\mathrm{SC})+0.469(\mathrm{RC})$

where: $\mathrm{HC}=$ human capital, $\mathrm{SC}=$ structural capital, $\mathrm{RC}=$ relational capital. 


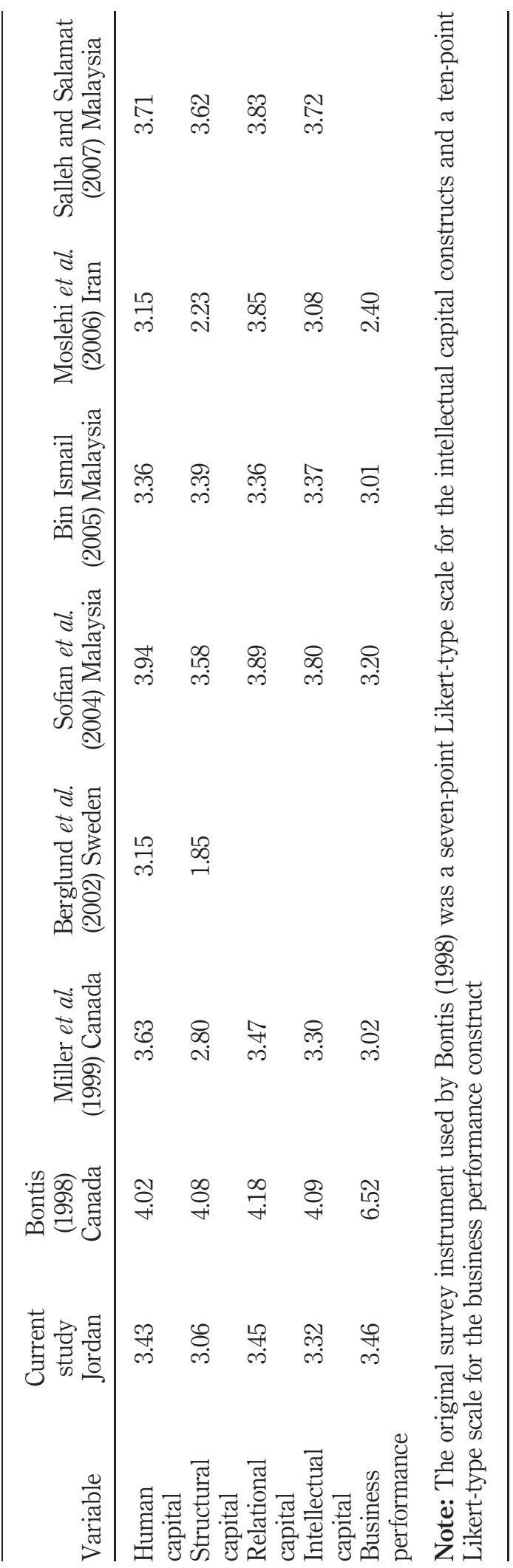

IC and business performance

113

Table II.

Comparison among mean scores across previous studies 
$\mathrm{MD}$

48,1

114

\begin{tabular}{llccccccccccccc}
\hline & Variable & 1 & 2 & 3 & 4 & 5 & 6 & 7 & 8 & 9 & 10 & 11 & 12 & 13 \\
\hline 1 & L\&E & & & & & & & & & & & & & \\
2 & E\&E & 0.712 & & & & & & & & & & & & \\
3 & I\&C & 0.701 & 0.745 & & & & & & & & & & & \\
4 & HC & 0.889 & 0.900 & 0.915 & & & & & & & & & & \\
5 & S\&P & 0.636 & 0.586 & 0.753 & 0.737 & & & & & & & & & \\
6 & R\&D & 0.546 & 0.498 & 0.579 & 0.603 & 0.631 & & & & & & & & \\
7 & IPR & 0.282 & 0.313 & 0.291 & 0.327 & 0.339 & 0.517 & & & & & & & \\
8 & SC & 0.579 & 0.557 & 0.638 & 0.659 & 0.769 & 0.874 & 0.796 & & & & & & \\
9 & ALA & 0.419 & 0.362 & 0.418 & 0.445 & 0.419 & 0.498 & 0.458 & 0.565 & & & & & \\
10 & R.PCS & 0.632 & 0.509 & 0.619 & 0.654 & 0.604 & 0.535 & 0.298 & 0.571 & 0.461 & & & & \\
11 & K.PCS & 0.603 & 0.529 & 0.600 & 0.643 & 0.596 & 0.513 & 0.406 & 0.609 & 0.462 & 0.711 & & & \\
12 & RC & 0.652 & 0.553 & 0.646 & 0.687 & 0.640 & 0.619 & 0.472 & 0.699 & 0.801 & 0.849 & 0.851 & & \\
13 & IC & 0.784 & 0.742 & 0.816 & 0.868 & 0.808 & 0.800 & 0.621 & 0.902 & 0.680 & 0.711 & 0.784 & 0.891 & \\
14 & BP & 0.564 & 0.534 & 0.641 & 0.647 & 0.598 & 0.550 & 0.258 & 0.557 & 0.375 & 0.729 & 0.609 & 0.670 & 0.698
\end{tabular}

Table III.

Correlation matrix

Note: All correlation values are significant at the 0.01 level (two-tailed)

The coefficients show that the relational capital construct has the most substantive association with its higher order construct. Several lower order models were then tested to evaluate how the items would load on to their respective constructs as follows:

EQ2. Human capital $=0.919+0.464(\mathrm{I} \& \mathrm{C})+0.243(\mathrm{~L} \& \mathrm{E})+0.435(\mathrm{E} \& \mathrm{E})$.

where: $\mathrm{I} \& \mathrm{C}=$ innovation $\&$ creation, $\mathrm{L} \& \mathrm{E}=$ learning $\&$ education $\mathrm{E} \& \mathrm{E}=$ experience and expertise.

EQ3. Structural capital $=1.521+0.390(\mathrm{~S} \& \mathrm{P})+0.245(\mathrm{R} \& \mathrm{D})-0.031(\mathrm{IPR})$.

where: $\mathrm{S} \& \mathrm{P}=$ systems $\&$ programs, $\mathrm{R} \& \mathrm{D}=$ research $\&$ development, $\mathrm{IPR}=$ intellectual property rights.

EQ4. Relational capital $=0.548+0.622$ (R.PSC) +0.184 (K.PSC) +0.016 (ALA)

where: R.PSC $=$ relations with partners, suppliers and customers

K.PSC $=$ knowledge about partners, suppliers and customers

$\mathrm{ALA}=$ alliances, licensing and agreements.

From $E Q 2$, it is determined that innovation and creation (0.464) plays a dominant role in describing the latent construct of human capital. From EQ3, systems and programs $(0.390)$ have the largest coefficient whereas intellectual property rights has a negative value $(-0.031)$. This negative result is expected since various authors (see Choo and Bontis, 2002; Bontis, 2002) have argued that intellectual property and intellectual capital are in fact mutually exclusive with the former representing assets that are legally protectable (e.g. patents, copyrights, trademarks) and the latter not (e.g. ideas, trade secrets). From $E Q 4$, relations with partners, suppliers and customers (0.622) is the strongest indicator of the latent construct relational capital.

\section{Implications for research}

The results of this study have shown that there is in fact strong and positive evidence that pharmaceutical firms in Jordan are managing intellectual capital effectively and 


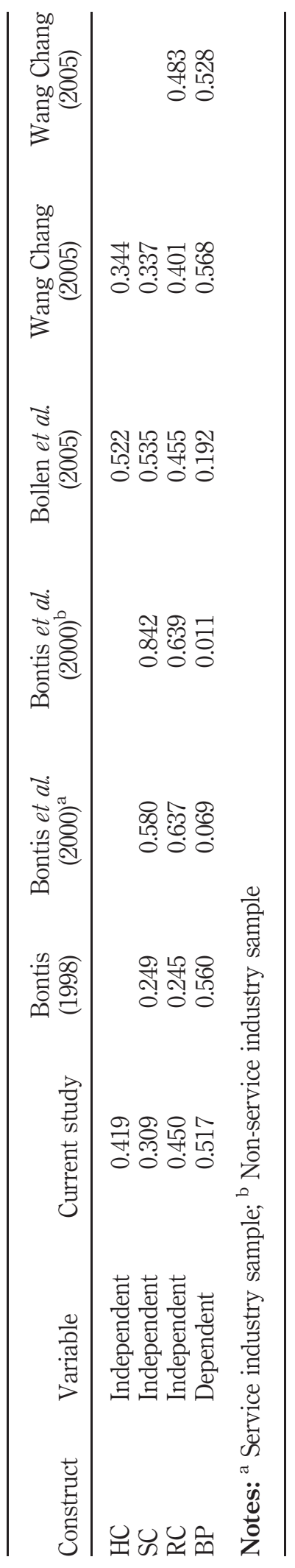

IC and business
performance

115

Table IV. Explanatory power $\left(R^{2}\right)$ compared with previous studies 
$\mathrm{MD}$

48,1

116

that in turn is influencing business performance positively. The results of this study have also corroborated previous research that has taken place in different national and industry contexts. It is argued that the generalizability of these results is supported with confidence due to the full sampling of the JAPM organizations. The following recommendations are for future academic research:

(1) This particular study was directed towards the managers of JAPM organizations and as such, data was collected from a specific level of the organizational hierarchy. To test the robustness of the findings, it would be wise to consider surveying front-line employees as well boards of directors.

(2) Although this study focused on the pharmaceutical industry specifically, there is ample opportunity to study other knowledge-intensive industries in Jordan (e.g. software development, consulting, retail). Further empirical work is needed to test the degree to which the findings can be generalized to other industries.

(3) A unique contribution of this study is the testing of intellectual capital concepts within Jordan. There are several other countries both in the Middle East and elsewhere that would benefit testing these concepts in a non-Anglophonic setting.

(4) Although most variables used in this research have high reliability and validity as tested in several previous contexts, there is always opportunity for refinement, especially when survey instruments require translation.

(5) One can also exploring the usefulness of studying other possible constructs that would influence intellectual capital such a brand, reputation and gender empowerment.

(6) Developing an important consideration in this study is the absence of lag time when determining the influence that constructs have on business performance. To assess the timing of this relationship, one has to examine these variables longitudinally over time.

\section{Implications for practice}

In the light of the academic research results, the following recommendations can be suggested for practitioners:

(1) When developing an intellectual capital strategy, it is important to consider the relative importance of variables within each construct. For example, systems and programs is fundamentally the most important measure within the latent construct of structural capital.

\begin{tabular}{lccc}
\hline Paired constructs & Current study & Bontis (1998) & Bin Ismail (2005) \\
\hline HC-SC & $0.659^{*}$ & $0.492^{*}$ & $0.524^{*}$ \\
SC-RC & $0.699^{*}$ & 0.197 & $0.555^{*}$ \\
HC-RC & $0.687^{*}$ & $0.499^{*}$ & $0.510^{*}$ \\
HC-BP & $0.647^{*}$ & $0.509^{*}$ & $0.520^{*}$ \\
SC-BP & $0.557^{*}$ & $0.508^{*}$ & $0.501^{*}$ \\
RC-BP & $0.670^{*}$ & $0.639^{*}$ & $0.641^{*}$
\end{tabular}

Note: *Correlation is significant at the 0.01 level (two-tailed) 
(2) The optimal procedure for JAPM organizations is to focus their efforts on managing all three components of intellectual capital in order to increase their business performance.

$\mathrm{IC}$ and business performance

(3) When comparing these Jordanian results to other studies, it is important to note that Structural Capital was the lowest mean score construct within Jordan as well as across most other countries. The implication here is that JAPM organizations must increase their investment in telecommunications and collaborative information technology tools that can help codify tacit knowledge. At present, the gap between human capital (3.43) and structural capital (3.06) is relatively high which provides insight as to the challenges that JAPM organizations face in converting the expertise that's inside employees' minds into the systems and structures of the firm.

(4) It is recommended that organizations identify key people and assign them the role as intellectual capital champion. This individual would be responsible for preparing a plan for managing intellectual capital and linking it to the organization's strategic goals. At the same time, JAPM organizations should consider the establishment of the post of Chief Intellectual Capital Management Officer (CICMO) or Chief Knowledge Officer (CKO).

(5) Leadership development and training programs within JAPM organizations should include a focus on the issue of intellectual capital measurement and management.

(6) JAPM organizations would be wise to establish a consortium network in which they would benchmark relative measures of intellectual capital against each other on a consistent basis. This is a viable option given the relatively small number of members at this point.

(7) JAPM organizations should consider the publication of an intellectual capital report so that management is inclined to monitor this phenomenon while at the same time preparing traditional financial statements.

To get the maximum benefits from the concept of intellectual capital, it should be considered at all four levels: individual, group, organization and country. In a study sponsored by the United Nations, Jordan was identified as a nation with high levels of human capital but relatively low levels of process (structural) capital (Bontis, 2004). It is important for the Jordanian government to harvest the full potential of its people by investing in appropriate technological infrastructure so that human capital can be converted (or processed) into increased wealth and a higher standard of living. This can be achieved for organizations regardless of size (Serenko et al., 2007).

Social capital is the capacity of a nation to create and develop entrepreneurs, inventors, innovators and leaders. Social capital improves the capabilities of individuals and organizations for future benefits. It emphasizes high co-operation among society members, government, academic institutions, and organizations.

The concept of intellectual capital is a newly emerging concept, and until now, it is not fully understood by most organizations in Jordan or the Arab world. This study represents a major foundation in elevating this concept within the Jordanian business community. As such it represents (to the best of the authors' knowledge) only the third piece of Anglophonic research focused on an Arab country since Seleim et al. (2004, 2007) studied software firms in Egypt. 
$\mathrm{MD}$

48,1

118

\section{References}

Andreou, A. and Bontis, N. (2007), "A model for resource allocation using operational knowledge assets”, The Learning Organization: An International Journal, Vol. 14 No. 4, pp. 345-74.

Berglund, R., Grönvall, T., Johnson, M. and Edvinsson, L. (2002), "Intellectual capital's leverage on market value", unpublished Master's thesis, Lund School of Economics and Management, Lund University, Lund.

Bin Ismail, M. (2005), "The influence of intellectual capital on the performance of Telekom Malaysia (Telco)", unpublished Doctoral dissertation, Business \& Advanced Technology Centre, University of Technology Malaysia, Skudai.

Bollen, L., Vergauwen, P. and Schnieders, S. (2005), "Linking intellectual capital and intellectual property to company performance", Management Decision, Vol. 43 No. 9, pp. 1161-85.

Bontis, N. (1998), "Intellectual capital: an exploratory study that develops measures and models", Management Decision, Vol. 36 No. 2, pp. 63-76.

Bontis, N. (1999), "Managing organizational knowledge by diagnosing intellectual capital: framing and advancing the state of the field", International Journal of Technology Management, Vol. 18 Nos 5-8, pp. 433-62.

Bontis, N. (2001), "Assessing knowledge assets: a review of the models used to measure intellectual capital”, International Journal of Management Reviews, Vol. 3 No. 1, pp. 41-60.

Bontis, N. (2002), World Congress on Intellectual Capital Readings, KMCI Butterworth-Heinemann Press, Boston, MA.

Bontis, N. (2003), "Intellectual capital disclosure in Canadian corporations", Journal of Human Resource Costing and Accounting, Vol. 7 Nos 1/2, pp. 9-20.

Bontis, N. (2004), "National Intellectual Capital Index: a United Nations initiative for the Arab region", Journal of Intellectual Capital, Vol. 5 No. 1, pp. 13-39.

Bontis, N. and Fitz-enz, J. (2002), "Intellectual capital ROI: a causal map of human capital antecedents and consequents", Journal of Intellectual Capital, Vol. 3 No. 3, pp. 223-47.

Bontis, N. and Girardi, J. (2000), "Teaching knowledge management and intellectual capital lessons: an empirical examination of the TANGO simulation”, International Journal of Technology Management, Vol. 27 Nos 5-8, pp. 545-55.

Bontis, N. and Serenko, A. (2009), "A follow-up ranking of academic journals", Journal of Knowledge Management, Vol. 13 No. 1.

Bontis, N., Crossan, M. and Hulland, J. (2002), "Managing an organizational learning system by aligning stocks and flows", Journal of Management Studies, Vol. 39 No. 4, pp. 437-69.

Bontis, N., Keow, W. and Richardson, S. (2000), "Intellectual capital and the nature of business in Malaysia”, Journal of Intellectual Capital, Vol. 1 No. 1, pp. 85-100.

Bontis, N., Dragonetti, N., Jacobsen, K. and Roos, G. (1999), “The knowledge toolbox: a review of the tools available to measure and manage intangible resources", European Management Journal, Vol. 17 No. 4, pp. 391-402.

Booker, L., Bontis, N. and Serenko, A. (2008), "The relevance of knowledge management and intellectual capital research", Knowledge and Process Management, Vol. 15 No. 4, pp. 235-46.

Cabrita, M. and Bontis, N. (2008), "Intellectual capital and business performance in the Portuguese banking industry", International Journal of Technology Management, Vol. 43 Nos 1-3, pp. 212-37. 
Cabrita, M., Landeiro de Vaz, J. and Bontis, N. (2007), "Modelling the creation of value from intellectual capital: a Portuguese banking perspective", International Journal of Knowledge and Learning, Vol. 3 Nos 2/3, pp. 266-80.

Chen, M.C. (2004), "Intellectual capital and competitive advantages: the case of TTY", Journal of Business Chemistry, Vol. 1 No. 1, pp. 14-20.

Choo, C.W. and Bontis, N. (2002), The Strategic Management of Intellectual Capital and Organizational Knowledge, Oxford University Press, New York, NY.

Collis, D.J. (1996), "Organizational capability as a source of profit", in Moingeon, B. and Edmondson, A. (Eds), Organizational Learning and Competitive Advantage, Sage, London.

Cuganesan, S. (2005), "Intellectual capital-in-action and value creation: a case study of knowledge transformations in an innovation project", Journal of Intellectual Capital, Vol. 6 No. 3, pp. 357-73.

Curado, C. and Bontis, N. (2006), "The knowledge based-view of the firm and its theoretical precursor", International Journal of Learning and Intellectual Capital, Vol. 3 No. 4, pp. 367-81.

Curado, C. and Bontis, N. (2007), "Managing intellectual capital: the MIC Matrix", International Journal of Knowledge and Learning, Vol. 3 Nos 2/3, pp. 316-28.

Daum, J.H. (2005), "Intangible assets-based enterprise management: a practical approach", Proceedings of 2005 PMA IC Symposium, Stern School of Business, New York University, Manhattan, 15 December 2005.

DeVol, R.C., Wong, P., Bedroussian, A., Wallace, L., Ki, J., Murphy, D. and Koepp, R. (2004), Bio-Pharmaceutical Industry Contributions to State and US Economics, Milken Institute, San Diego, CA.

Edvinsson, L. and Malone, M. (1997), Intellectual Capital: Realising Your Company's True Value by Finding its Hidden Brainpower, HarperCollins, New York, NY.

Firer, S. and Stainbank, L. (2003), "Testing the relationship between intellectual capital and a company's performance: evidence from South Africa", Meditari Accountancy Research, Vol. 11, pp. 25-44.

Fornell, C. and Larcker, D.F. (1981), "Evaluating structural equation models with unobservable variables and measurement error", Journal of Marketing Research, Vol. 18 No. 1, pp. 39-50.

Gallego, I. and Rodriguez, L. (2005), "Situation of intangible assets in Spanish firms: an empirical analysis", Journal of Intellectual Capital, Vol. 6 No. 1, pp. 105-26.

Heimeriks, K.H. and Duysters, G.M. (2003), “Alliance capability as mediator between experience and alliance performance: an empirical investigation into the alliance capability development process", ECIS Working Papers 03.18, Department of Technology Management, Eindhoven.

Hermans, R. (2004), International Mega-Trends and Growth Prospects of the Finnish Biotechnology Industry, ETLA - The Research Institute of the Finnish Economy, Helsinki.

Hijjawi, A. (2006), Data Bank, The Jordanian Association of Pharmaceutical Manufacturers, Amman.

Huang, C.J. and Liu, C.J. (2005), "Exploration for the relationship between innovation, IT and performance", Journal of Intellectual Capital, Vol. 6 No. 2, pp. 237-52.

Hulland, J.S. (1999), "Use of Partial Least Squares (PLS) in strategic management research: a review of four recent studies”, Strategic Management Journal, Vol. 20 No. 2, pp. 195-204.

Kannan, G. and Aulbur, W. (2004), "Intellectual capital: measurement effectiveness", Journal of Intellectual Capital, Vol. 5 No. 3, pp. 389-413.
$\mathrm{IC}$ and business performance 
$\mathrm{MD}$

48,1

120
Kristandl, G. and Bontis, N. (2007), "Defining intangible assets and intellectual capital", Management Decision, Vol. 45 No. 9, pp. 1510-24.

Kukko, M., Hannula, M. and Okkonen, J. (2003), "The state of intellectual capital management in the Finnish Top 50 companies", Proceedings of I-Know, Gram, Finland, July 4.

Lim, L.L.K. (2002), "Human capital: an examination of the indicators from two perspectives", working paper, Aberystwyth University, Aberystwyth.

Luscombe, N. (1993), “A learning experience”, CA Magazine, February, p. 3.

Miller, M., DuPont, B.D., Fera, V., Jeffrey, R., Mahon, B., Payer, B.M. and Starr, A. (1999), "Measuring and reporting intellectual capital from a diverse Canadian industry perspective: experiences, issues and prospects", Proceedings of the OECD Symposium, Amsterdam, June 9-11.

Moslehi, A., Mohagharl, A., Badie1, K. and Lucas, C. (2006), "Introducing a toolbox for IC measurement in the Iran insurance industry", The Electronic Journal of Knowledge Management, Vol. 4 No. 2, pp. 169-80.

O’Donnell, D., Bontis, N., O'Regan, P., Kennedy, T., Cleary, P. and Hannigan, A. (2004), “CFOs in eBusiness: eArchitects or foot-soldiers?", Knowledge and Process Management, Vol. 11 No. 2, pp. 105-16.

O’Donnell, D., Tracey, M., Henriksen, L.B., Bontis, N., Cleary, P., Kennedy, T. and O'Regan, P. (2006), "On the 'essential condition' of intellectual capital-labour", Journal of Intellectual Capital, Vol. 7 No. 1, pp. 111-28.

O'Regan, P., O'Donnell, D., Kennedy, T., Bontis, N. and Cleary, P. (2001), "Perceptions of intellectual capital: Irish evidence", Journal of Human Resource Costing and Accounting, Vol. 6 No. 2, pp. 29-38.

O'Regan, P., O’Donnell, D., Kennedy, T., Bontis, N. and Cleary, P. (2005), "Board composition, non-executive directors and governance cultures in Irish ICT firms: a CFO perspective", Corporate Governance: International Journal of Business in Society, Vol. 5 No. 4, pp. 56-63.

Podsakoff, P.M. and Organ, D.W. (1986), "Self-report in organizational research: problems and prospects", Journal of Management, Vol. 12 No. 4, pp. 531-44.

Roos, J., Roos, G., Dragonetti, N.C. and Edvinsson, L. (1997), Intellectual Capital: Navigating in the New Business Landscape, Macmillan, Basingstoke.

Sällebrant, T., Hansen, J., Bontis, N. and Hofman-Bang, P. (2007), "Managing risk with intellectual capital statements", Management Decision, Vol. 45 No. 9, pp. 1470-83.

Salleh, A. and Selamat, F. (2007), "Intellectual capital management in Malaysian public listed companies international", Review of Business Research Papers, Vol. 3 No. 2, pp. 262-74.

Seleim, A., Ashour, A. and Bontis, N. (2004), "Intellectual capital in Egyptian software firms", The Learning Organization: An International Journal, Vol. 11 Nos 4/5, pp. 332-46.

Seleim, A., Ashour, A. and Bontis, N. (2007), "Human capital and organizational performance: a study of Egyptian software companies", Management Decision, Vol. 45 No. 4, pp. 789-901.

Seng, J.L., Lin, T.H. and Chaing, S.W. (2004), "An exploratory set of indicators between information technology and process capital and innovation capital: based on a sample case", International Forum of Intellectual Capital in Taiwan (NICRC), National Chengchi University, Taiwan.

Serenko, A. and Bontis, N. (2004), "A model of user adoption of mobile portals", Quarterly Journal of Electronic Commerce, Vol. 4 No. 1, pp. 69-98.

Serenko, A. and Bontis, N. (2009), "Global ranking of knowledge management and intellectual capital academic journals", Journal of Knowledge Management, Vol. 13 No. 1. 
Serenko, A., Bontis, N. and Hardie, T. (2007), "Knowledge flow and organizational size: a proposed theoretical link", Journal of Intellectual Capital, Vol. 8 No. 4, pp. 610-27.

Sofian, S., Tayles, M.E. and Pike, R.H. (2004), "Intellectual capital: an evolutionary change in management accounting practices”, Working Paper Series No. 04/29, Bradford University School of Management, Bradford.

Stewart, T. (1997), Intellectual Capital: The New Wealth of Organizations, Doubleday/Currency, New York, NY.

Sveiby, K.E. (1997), The New Organizational Wealth: Managing and Measuring Knowledge-Based Assets, Berrett-Koehler, New York, NY.

Tomer, J.F. (2005), "Personal capital and emotional intelligence: an increasingly important intangible source of economic growth", Eastern Economic Journal, Vol. 3, pp. 453-70.

Trevinyo-Rodriguez, R.N. and Bontis, N. (2007), "The role of intellectual capital in Mexican family-based businesses: understanding their soul, brain and heart”, Journal of Information and Knowledge Management, Vol. 6 No. 3, pp. 189-200.

Wang, W.Y. and Chang, C. (2005), "Intellectual capital and performance in causal models: evidence from the information technology industry in Taiwan”, Journal of Intellectual Capital, Vol. 6 No. 2, pp. 222-36.

Westhuizen, C.V.D. (2005), "Intellectual capital management in a retail company in South Africa", unpublished dissertation, Department of Information and Knowledge Management, University of Johannesburg, Soweto.

Williams, L.J., Edwards, J.R. and Vandenberg, R.J. (2003), "Recent advances in causal modeling methods for organizational and management research", Journal of Management, Vol. 29 No. 6, pp. 903-36.

Xiaojun, X. (2004), "Managing intellectual capital transformation", working paper, School of Management, Fudan University, Shanghai.

Zambon, S. (2002), "Accounting, intangible and intellectual capital: an overview of the issues and some considerations", Working Paper 4, University of Ferrara, Ferrara.

Zucker, L.G., Darby, M.R. and Brewer, M.B. (1994), "Intellectual capital and the birth of US biotechnology enterprise”, Working Paper Series 4653, NBER, Cambridge.

\section{Further reading}

Bontis, N. (2001), "CKO wanted - evangelical skills necessary: a review of the chief knowledge officer position", Knowledge and Process Management, Vol. 8 No. 1, pp. 29-38.

Bontis, N. and Serenko, A. (2009), "Longitudinal knowledge strategising in a long-term healthcare organisation", International Journal of Technology Management, Vol. 47 Nos 1-3, pp. 276-97.

Cleary, P., O'Regan, P., O'Donnell, D., Kennedy, T. and Bontis, N. (2007), "Positioning management accounting in the intellectual capital agenda", International Journal of Accounting, Auditing and Performance Evaluation, Vol. 4 Nos 4/5, pp. 336-59.

Kristandl, G. and Bontis, N. (2007), "The impact of voluntary disclosure on cost of equity capital and risk premium estimates in a temporal setting", Journal of Intellectual Capital, Vol. 8 No. 4, pp. 577-94.

Serenko, A. and Bontis, N. (2004), "Meta-review of knowledge management and intellectual capital literature: citation impact and research productivity rankings", Knowledge and Process Management, Vol. 11 No. 3, pp. 185-98.

IC and business performance 
48,1

\section{A - General Information}

Intellectual Capital has often been described as the difference between what a firm's market value is and the cost of replacing its assets. Therefore, this (often-positive) difference can be described as "those things that we normally cannot put a price tag on" such as expertise, knowledge, and a firm's organizational learning ability.

There are three elements encompassing Intellectual Capital: 1) Human capital can be described as the firm's collective capability to extract the best solutions from the knowledge of its individuals, that which is in the minds of individuals; 2) Structural capital can be thought of as the firm's organizational capabilities to meet market requirements, what is left after employees go home for the night; 3 ) Relational (customer) capital refers to firm's relationships e.g. with the customers, suppliers and partners.

Business performance (productivity, profitability and market valuation). Just to remind you: Productivity means the relation between input and output of processes and transactions. Profitability means earnings before interest and tax (EBIT). Market valuation means the value of the whole organization or stock value.

\section{B - Questionnaire Items}

The following 90 items tap into Intellectual Capital and its effect on company's business performance. Please, answer these questions based on actual and current situation and not on beliefs.

[ 1 = strongly disagree, $2=$ disagree, $3=$ neutral, $4=$ agree, $5=$ strongly agree $]$ based on how you feel about the statement.

\section{Learning and education:}

\section{Human Capital}

\begin{tabular}{|c|c|c|c|c|c|c|}
\hline & $\begin{array}{l}\text { The competence of company's employees as a whole is equal to } \\
\text { the most ideal level (matching with their work requirements and } \\
\text { responsibilities) }\end{array}$ & 1 & 2 & 3 & 4 & \\
\hline 2 & $\begin{array}{l}\text { The company gets the most out of its employees when they } \\
\text { cooperate with one another in team tasks. }\end{array}$ & 1 & 2 & 3 & 4 & \\
\hline 3 & $\begin{array}{l}\text { Company's employees undergo continuous training programs } \\
\text { every year. }\end{array}$ & 1 & 2 & 3 & 4 & \\
\hline 4 & employees continuously learn from others & 1 & 2 & 3 & 4 & \\
\hline 5 & $\begin{array}{l}\text { ed personnel is on average compared } \\
\mathrm{D} \text {, Master and Bachelor degrees com }\end{array}$ & 1 & 2 & 3 & 4 & \\
\hline 6 & $\begin{array}{l}\text { Company devotes a lot of time and effort to update and } \\
\text { develops employees' knowledge and skills. }\end{array}$ & 1 & 2 & 3 & 4 & \\
\hline 7 & $\begin{array}{l}\text { Company's market share has been continually improving } \\
\text { the past few years. }\end{array}$ & 1 & 2 & 3 & 4 & \\
\hline 8 & $\begin{array}{l}\text { Employees' learning and education affect con } \\
\text { productivity. }\end{array}$ & 1 & 2 & 3 & & \\
\hline
\end{tabular}

Figure A1.

(Continued) 


\begin{tabular}{|c|c|c|c|c|c|c|}
\hline 9 & $\begin{array}{l}\text { Employees' learning and education affect company's } \\
\text { profitability. }\end{array}$ & 1 & 2 & 3 & 4 & 5 \\
\hline 10 & $\begin{array}{l}\text { Employees' learning and education affect company's market } \\
\text { value (stock value). }\end{array}$ & 1 & 2 & 3 & 4 & 5 \\
\hline
\end{tabular}

\section{IC and business performance}

Experience and expertise

\begin{tabular}{|l|l|l|l|l|l|l|}
\hline 11 & Company's employees are experts in their respective areas. & 1 & 2 & 3 & 4 & 5 \\
\hline 12 & Company's employees consistently perform at their best. & 1 & 2 & 3 & 4 & 5 \\
\hline 13 & $\begin{array}{l}\text { Company's employees generally give it their all, which makes } \\
\text { this company different from others in the industry. }\end{array}$ & 1 & 2 & 3 & 4 & 5 \\
\hline 14 & $\begin{array}{l}\text { Company's employees have worked for many years in the firm } \\
\text { (employee turnover is very low) }\end{array}$ & 1 & 2 & 3 & 4 & 5 \\
\hline 15 & The company prides itself on being efficient. & 1 & 2 & 3 & 4 & 5 \\
\hline 16 & The staff are highly professional. & 2 & 3 & 4 & 5 \\
\hline 17 & $\begin{array}{l}\text { The company has the lowest costs per transaction of any in the } \\
\text { industry. }\end{array}$ & 1 & 2 & 3 & 4 & 5 \\
\hline 18 & $\begin{array}{l}\text { Employees' experience and expertise affect company's } \\
\text { productivity. }\end{array}$ & 1 & 2 & 3 & 4 & 5 \\
\hline 19 & $\begin{array}{l}\text { Employees' experience and expertise affect company's } \\
\text { profitability. }\end{array}$ & 1 & 2 & 3 & 4 & 5 \\
\hline 20 & $\begin{array}{l}\text { Employees' experience and expertise affect company's market } \\
\text { value (stock value). }\end{array}$ & 1 & 2 & 3 & 4 & 5 \\
\hline
\end{tabular}

\section{Innovation and creation}

\begin{tabular}{|c|c|c|c|c|c|c|}
\hline 21 & $\begin{array}{l}\text { Company's employees are considered creative and bright } \\
\text { compared with other companies in the industry. }\end{array}$ & 1 & 2 & 3 & 4 & 5 \\
\hline 22 & $\begin{array}{l}\text { Company's employees are keen to voice their opinions in } \\
\text { group discussions. }\end{array}$ & 1 & 2 & 3 & 4 & 5 \\
\hline 23 & Company's employees usually come up with new ideas. & 1 & 2 & 3 & 4 & 5 \\
\hline 24 & $\begin{array}{l}\text { Large numbers of new products are launched compared with } \\
\text { competitors. }\end{array}$ & 1 & 2 & 3 & 4 & 5 \\
\hline 25 & $\begin{array}{l}\text { Company's employees are continuously encouraged to bring } \\
\text { new knowledge and ideas to the business and share their } \\
\text { knowledge with their colleagues. }\end{array}$ & 1 & 2 & 3 & 4 & 5 \\
\hline 26 & $\begin{array}{l}\text { Company's employees are satisfied with their company's } \\
\text { innovation policies and programs. }\end{array}$ & 1 & 2 & 3 & 4 & 5 \\
\hline 27 & $\begin{array}{l}\text { Company's employees are highly motivated and committed to } \\
\text { share new great ideas within the company, as it should be. }\end{array}$ & 1 & 2 & 3 & 4 & 5 \\
\hline 28 & $\begin{array}{l}\text { Employees' innovation and creation affect company's } \\
\text { productivity. }\end{array}$ & 1 & 2 & 3 & 4 & 5 \\
\hline 29 & $\begin{array}{l}\text { Employees' innovation and creation affect company's } \\
\text { profitability. }\end{array}$ & 1 & 2 & 3 & 4 & 5 \\
\hline 30 & $\begin{array}{l}\text { Employees' innovation and creation affect company's market } \\
\text { value (stock value). }\end{array}$ & 1 & 2 & 3 & 4 & 5 \\
\hline
\end{tabular}

(Continued) 
$\mathrm{MD}$

48,1

124

Systems and programs

\section{Structural Capital}

\begin{tabular}{|l|l|l|l|l|l|l}
\hline 31 & $\begin{array}{l}\text { The company has succession training programs for each and } \\
\text { every post/position (major positions) }\end{array}$ & 1 & 2 & 3 & 4 & 5 \\
\hline 32 & $\begin{array}{l}\text { The company's culture and atmosphere are supportive and } \\
\text { comfortable. }\end{array}$ & 1 & 2 & 3 & 4 & 5 \\
\hline 33 & $\begin{array}{l}\text { The company's recruitment programs are comprehensive; and } \\
\text { dedicated to hiring the best candidates available. }\end{array}$ & 1 & 2 & 3 & 4 & 5 \\
\hline 34 & $\begin{array}{l}\text { The company has a well-developed reward system related to } \\
\text { performance. }\end{array}$ & 1 & 2 & 3 & 4 & 5 \\
\hline 35 & $\begin{array}{l}\text { The company supports their employees by constantly } \\
\text { upgrading their skills and education whenever it is necessary. }\end{array}$ & 1 & 2 & 3 & 4 & 5 \\
\hline 36 & $\begin{array}{l}\text { Staff have sufficient influence over decisions made within the } \\
\text { company. }\end{array}$ & 1 & 2 & 3 & 4 & 5 \\
\hline 37 & 1 & 2 & 3 & 4 & 5 \\
\hline 38 & $\begin{array}{l}\text { The company is not a "bureaucratic nightmare". } \\
\text { productivity. }\end{array}$ & 1 & 2 & 3 & 4 & 5 \\
\hline 39 & $\begin{array}{l}\text { Company's systems and programs affect company's } \\
\text { profitability. }\end{array}$ & 1 & 2 & 3 & 4 & 5 \\
\hline 40 & $\begin{array}{l}\text { Company's systems and programs affect company's market } \\
\text { value (stock value). }\end{array}$ & 1 & 2 & 3 & 4 & 5 \\
\hline
\end{tabular}

\section{Research \& Development (R\&D)}

\begin{tabular}{|l|l|l|l|l|l|l|}
\hline 41 & The company is considered a research leader. & 2 & 3 & 4 & 5 \\
\hline 42 & The company continuously develops work processes. & 1 & 2 & 3 & 4 & 5 \\
\hline 43 & $\begin{array}{l}\text { The company continuously develops and re-organizes itself } \\
\text { based on R\&D (e.g. structure and responsibilities). }\end{array}$ & 1 & 2 & 3 & 4 & 5 \\
\hline 44 & $\begin{array}{l}\text { The company follows up and adopts the latest scientific and } \\
\text { technical development around the world. }\end{array}$ & 1 & 2 & 3 & 4 & 5 \\
\hline 45 & The systems and procedures of the company support innovation. & 1 & 2 & 3 & 4 & 5 \\
\hline 46 & $\begin{array}{l}\text { The company determines appropriate and adequate budget for } \\
\text { R\&D. }\end{array}$ & 1 & 2 & 3 & 4 & 5 \\
\hline 47 & $\begin{array}{l}\text { The company's board of management highly trust and support } \\
\text { the R\&D department. }\end{array}$ & 1 & 2 & 3 & 4 & 5 \\
\hline 48 & \begin{tabular}{l} 
Company's R\&D affects company's productivity. \\
\hline 49
\end{tabular} & 1 & 2 & 3 & 4 & 5 \\
\hline 50 & Company's R\&D affects company's profitability. & 2 & 3 & 4 & 5 \\
\hline
\end{tabular}

\section{Intellectual Property Rights (IPRs)}

\begin{tabular}{|c|c|c|c|c|c|c|}
\hline 51 & $\begin{array}{l}\text { The company sets clear strategies and procedures for IPRs } \\
\text { management }\end{array}$ & 1 & 2 & 3 & 4 & 5 \\
\hline 52 & The company monitors performance of the IPRs portfolio. & 1 & 2 & 3 & 4 & 5 \\
\hline 53 & $\begin{array}{l}\text { The company pursues a multiple strategy of licensing IPRs, } \\
\text { spinning out new organizations or disposing of them to other parties. }\end{array}$ & 1 & 2 & 3 & 4 & 5 \\
\hline 54 & $\begin{array}{l}\text { The company actively encourages and rewards creation and } \\
\text { extended use in order to maximize the income from IPRs. }\end{array}$ & 1 & 2 & 3 & 4 & 5 \\
\hline
\end{tabular}

Figure A1. 


\begin{tabular}{|c|c|c|c|c|c|c|}
\hline 55 & $\begin{array}{l}\text { IP is a key intellectual asset for top management, which is } \\
\text { considered for value creation. }\end{array}$ & 1 & 2 & 3 & 4 & 5 \\
\hline 56 & The company utilizes the IPRs to maximum level. & 1 & 2 & 3 & 4 & 5 \\
\hline 57 & $\begin{array}{l}\text { The company has high number of IPRs per year compared with } \\
\text { competitors. }\end{array}$ & 1 & 2 & 3 & 4 & 5 \\
\hline 58 & Company's IPRs affect company's productivity. & 1 & 2 & 3 & 4 & 5 \\
\hline 59 & Company's IPRs affect company's profitability. & 1 & 2 & 3 & 4 & 5 \\
\hline 60 & Company's IPRs affect company's market value (stock value). & 1 & 2 & 3 & 4 & 5 \\
\hline
\end{tabular}

\section{IC and business performance}

\section{Strategic alliances, licensing and agreements}

\section{Relational Capital}

\begin{tabular}{|c|c|c|c|c|c|c|}
\hline 61 & $\begin{array}{l}\text { The company is currently working on joint projects with many } \\
\text { other organizations. }\end{array}$ & 1 & 2 & 3 & 4 & 5 \\
\hline 62 & The company has diverse distribution channels. & 1 & 2 & 3 & 4 & 5 \\
\hline 63 & $\begin{array}{l}\text { High ratio of company's business is done with strategic } \\
\text { alliances. }\end{array}$ & 1 & 2 & 3 & 4 & 5 \\
\hline 64 & $\begin{array}{l}\text { The company has many and diverse alliances (R\&D, } \\
\text { manufacturing, marketing, distribution) }\end{array}$ & 1 & 2 & 3 & 4 & 5 \\
\hline 65 & $\begin{array}{l}\text { People from outside the company are consulted when } \\
\text { decisions are made within the company. }\end{array}$ & 1 & 2 & 3 & 4 & 5 \\
\hline 66 & $\begin{array}{l}\text { The company is able to learn and add value through its } \\
\text { partners. }\end{array}$ & 1 & 2 & 3 & 4 & 5 \\
\hline 67 & The company prides itself on being partnership-oriented. & 1 & 2 & 3 & 4 & 5 \\
\hline 68 & Company's strategic alliances affect company's productivity. & 1 & 2 & 3 & 4 & 5 \\
\hline 69 & Company's strategic alliances affect company's profitability. & 1 & 2 & 3 & 4 & 5 \\
\hline 70 & $\begin{array}{l}\text { Company's strategic alliances affect company's market value } \\
\text { (stock value). }\end{array}$ & 1 & 2 & 3 & 4 & 5 \\
\hline
\end{tabular}

\section{Customer and Supplier relations}

\begin{tabular}{|c|c|c|c|c|c|c|}
\hline 71 & $\begin{array}{l}\text { A poll of company's customers shows them to be loyal to the } \\
\text { company, and would indicate that they are generally satisfied. }\end{array}$ & 1 & 2 & 3 & 4 & 5 \\
\hline 72 & $\begin{array}{l}\text { When it comes to new business, the company's customers have } \\
\text { increasingly selected company's products versus competitors' } \\
\text { customers over the past few years. }\end{array}$ & 1 & 2 & 3 & 4 & 5 \\
\hline 73 & $\begin{array}{l}\text { The company capitalizes on customers' wants and needs by } \\
\text { continually striving to make them satisfied. }\end{array}$ & 1 & 2 & 3 & 4 & 5 \\
\hline 74 & The company devotes considerable time to select suppliers. & 1 & 2 & 3 & 4 & 5 \\
\hline 75 & $\begin{array}{l}\text { The company maintains a long-standing relationship with } \\
\text { suppliers. }\end{array}$ & 1 & 2 & 3 & 4 & 5 \\
\hline 76 & $\begin{array}{l}\text { The company has greatly reduced the time it takes to resolve a } \\
\text { customer's problem. }\end{array}$ & 1 & 2 & 3 & 4 & 5 \\
\hline 77 & $\begin{array}{l}\text { The company feels confident that their customers will continue } \\
\text { to do business with it. }\end{array}$ & 1 & 2 & 3 & 4 & 5 \\
\hline 78 & $\begin{array}{l}\text { Company's relationship with customer and supplier affects } \\
\text { company's productivity. }\end{array}$ & 1 & 2 & 3 & 4 & 5 \\
\hline
\end{tabular}


$\mathrm{MD}$

48,1

\begin{tabular}{|c|c|c|c|c|c|c|}
\hline 79 & $\begin{array}{l}\text { Company's relationship with customer and supplier affects } \\
\text { company's profitability. }\end{array}$ & 1 & 2 & 3 & 4 & 5 \\
\hline 80 & $\begin{array}{l}\text { Company's relationship with customer and supplier affects } \\
\text { company's market value (stock value). }\end{array}$ & 1 & 2 & 3 & 4 & 5 \\
\hline
\end{tabular}

\section{Customer Knowledge}

\begin{tabular}{|c|c|c|c|c|c|c|}
\hline 81 & $\begin{array}{l}\text { It is important for the company to share knowledge with its } \\
\text { partners. }\end{array}$ & 1 & 2 & 3 & 4 & 5 \\
\hline 82 & $\begin{array}{l}\text { The company gets as much feedback out of customers as } \\
\text { it possibly can under different circumstances. }\end{array}$ & 1 & 2 & 3 & 4 & 5 \\
\hline 83 & $\begin{array}{l}\text { Customer knowledge is widely distributed throughout the } \\
\text { company. }\end{array}$ & 1 & 2 & 3 & 4 & 5 \\
\hline 84 & Data about customers are continuously updated. & 1 & 2 & 3 & 4 & 5 \\
\hline 85 & The company has relatively complete data about the suppliers. & 1 & 2 & 3 & 4 & 5 \\
\hline 86 & $\begin{array}{l}\text { The company continually meets with customers to find out } \\
\text { what they want from it. }\end{array}$ & 1 & 2 & 3 & 4 & 5 \\
\hline 87 & $\begin{array}{l}\text { The company has a useful and updated information system in } \\
\text { use. }\end{array}$ & 1 & 2 & 3 & 4 & 5 \\
\hline 88 & $\begin{array}{l}\text { Company's knowledge about customers and suppliers affects } \\
\text { company's productivity. }\end{array}$ & 1 & 2 & 3 & 4 & 5 \\
\hline 89 & $\begin{array}{l}\text { Company's data about customers and suppliers affects } \\
\text { company's profitability. }\end{array}$ & 1 & 2 & 3 & 4 & 5 \\
\hline 90 & $\begin{array}{l}\text { Company's knowledge about customers and suppliers affects } \\
\text { company's market value (stock value). }\end{array}$ & 1 & 2 & 3 & 4 & \\
\hline
\end{tabular}

\section{C - Questionnaire Items}

The following 10 items are about the company's performance related to key competitors in the industry over the last few years and will be used for administrative and comparative purposes only. If you are not absolutely sure about an item, please just approximate. [1 $=$ bottom, $\mathbf{5}=$ top] based on the number that best corresponds to your answer.

How do you rank your company compared to the competitors:

\begin{tabular}{|l|l|l|l|l|l|l|}
\hline 91 & Industry leadership. & 1 & 2 & 3 & 4 & 5 \\
\hline 92 & Future outlook. & 1 & 2 & 3 & 4 & 5 \\
\hline 93 & Overall response to competition. & 1 & 2 & 3 & 4 & 5 \\
\hline 94 & Success rate in new product launches. & 1 & 2 & 3 & 4 & 5 \\
\hline 95 & Overall business performance and success. & 1 & 2 & 3 & 4 & 5 \\
\hline 96 & Employee productivity. & 1 & 2 & 3 & 4 & 5 \\
\hline 97 & Process (transaction) productivity. & 1 & 2 & 3 & 4 & 5 \\
\hline 98 & Sales growth. & 1 & 2 & 3 & 4 & 5 \\
\hline 99 & Profit growth. & 1 & 2 & 3 & 4 & 5 \\
\hline 100 & Company's market valuation (stock value). & 1 & 2 & 3 & 4 & 5 \\
\hline
\end{tabular}

(Continued)

Figure A1. 


\section{IC and business performance}

Please complete this section of the survey:

\begin{tabular}{|l|l|}
\hline Total No. of Employees: & \\
\hline Total 2005 Revenue: & \\
\hline Total 2006 Revenue: & \\
\hline Your Position (Title): & \\
\hline Company Name: & \\
\hline Company Address: & \\
\hline Telephone: & \\
\hline Fax: & \\
\hline E-mail: & \\
\hline Web-site URL: & \\
\hline
\end{tabular}

E-Please note that the researcher left this space for any comments the respondent wishes to state.

Thank you for completing the questionnaire.

Figure A1. 


\section{Appendix 2}

48,1

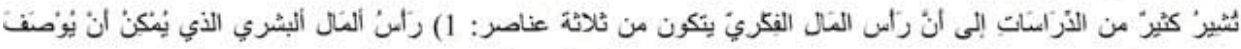

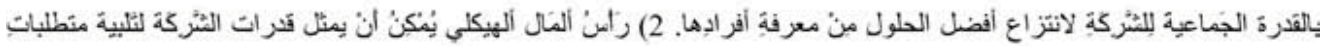

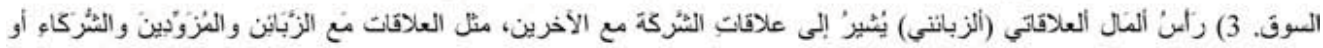
الخُلفاء.

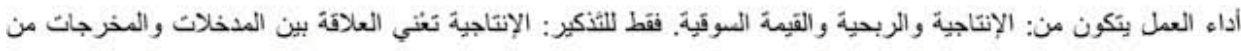

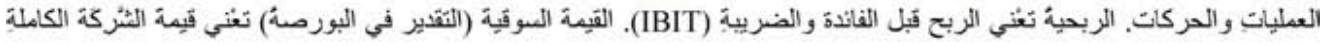

2) متغيرات رأس المال الفكري وعلاقتها بالأداء: (الفترات من 1 إلى 90).

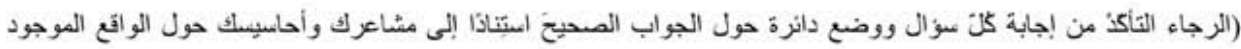

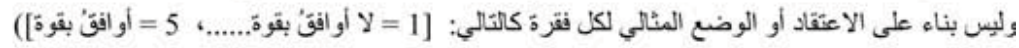
راسن ألمال ألبُشري

التعليم والثُطلم

\begin{tabular}{|c|c|c|}
\hline 5443221 & 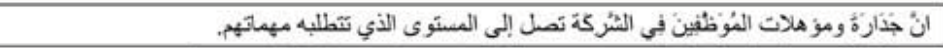 & \\
\hline $5 \begin{array}{llllll}5 & 4 & 3 & 2 & 1\end{array}$ & 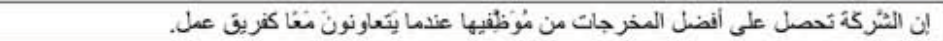 & 2 \\
\hline 544321 & 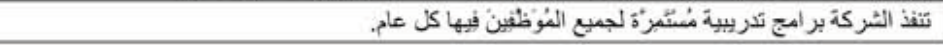 & 3 \\
\hline 544321 & 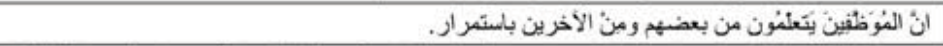 & 4 \\
\hline 543321 & 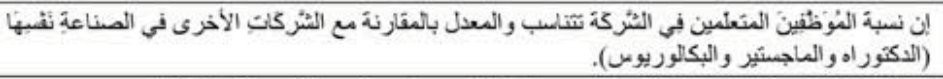 & 5 \\
\hline 544321 & 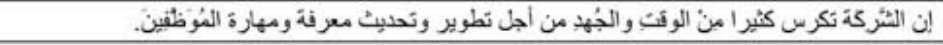 & 6 \\
\hline $5 \quad 4 \quad 3 \quad 21$ & 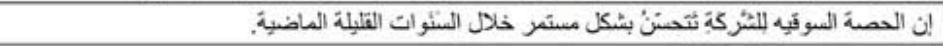 & 7 \\
\hline 5443221 & 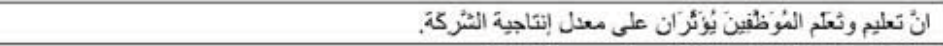 & 8 \\
\hline 5443221 & 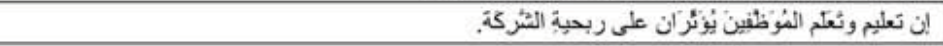 & 9 \\
\hline $5 \quad 4 \quad 3 \quad 21$ & 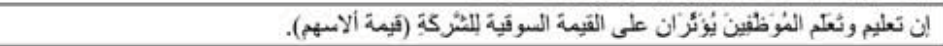 & 10 \\
\hline
\end{tabular}

Figure A2.

\begin{tabular}{|c|c|c|}
\hline \multicolumn{3}{|c|}{ 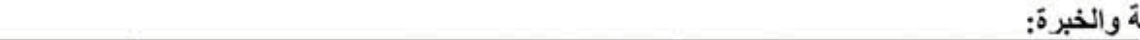 } \\
\hline 5443321 & 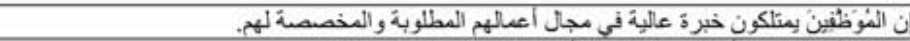 & 11 \\
\hline 544321 & 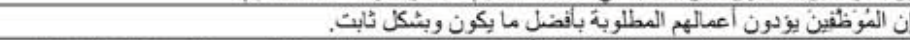 & 12 \\
\hline 543321 & 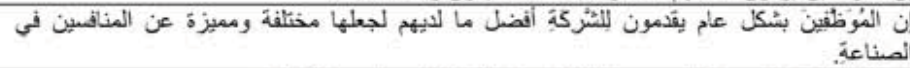 & 13 \\
\hline 544321 & 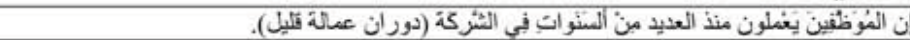 & 14 \\
\hline
\end{tabular}




\begin{tabular}{|c|c|c|}
\hline 54321 & إن الشزكة نَقتخر بكفاعتها. & 15 \\
\hline 54321 & 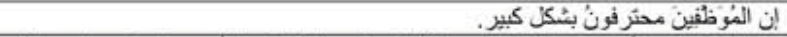 & 16 \\
\hline 5443221 & إن المشركة لدِيها أرخص تكلفة لكل حركة مقارنة مع المثركات الأخرى في نفس الصناعة. & 17 \\
\hline 5443221 & 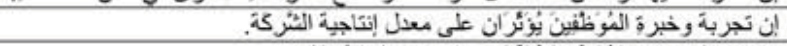 & 18 \\
\hline $5 \quad 4 \quad 3 \quad 21$ & 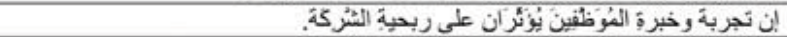 & 19 \\
\hline 544321 & 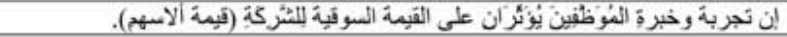 & 20 \\
\hline
\end{tabular}

\section{IC and business performance}

إبداع المُوظقين ونوليد الأفكار:

\begin{tabular}{|lllllll|l|}
\hline 5 & 4 & 3 & 2 & 1 \\
\hline 5 & 4 & 3 & 2 & 1
\end{tabular}

\section{رَاسن ألمّال ألهيكلي}

\begin{tabular}{|c|c|c|}
\hline \multicolumn{3}{|c|}{ 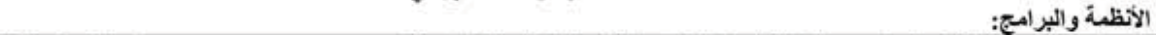 } \\
\hline 54321 & 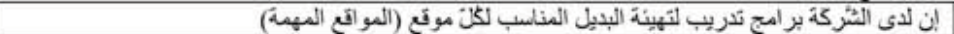 & 31 \\
\hline 543321 & 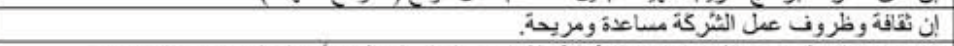 & 32 \\
\hline 543321 & 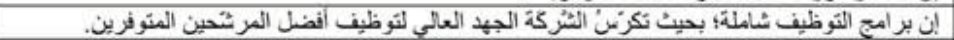 & 33 \\
\hline 543321 & إن لدى المثز كة نظام حوافز وجوائز مئطورا جدا ويركز على الأداو. & 34 \\
\hline 54321 & 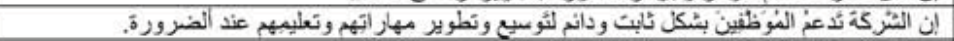 & 35 \\
\hline 543321 & 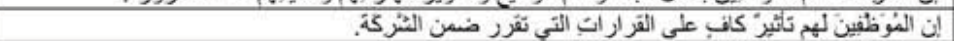 & 36 \\
\hline 543321 & 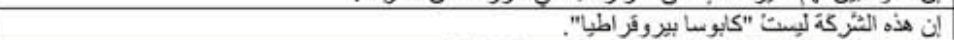 & 37 \\
\hline 543321 & 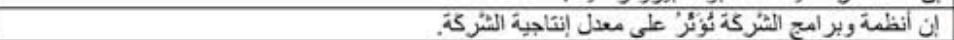 & 38 \\
\hline 54321 & 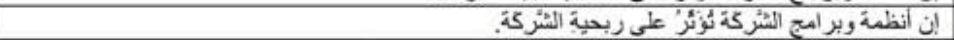 & 39 \\
\hline 543321 & 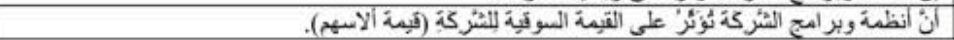 & 40 \\
\hline \multicolumn{3}{|c|}{ البحَتُ و التمطوير العلم } \\
\hline 54321 & 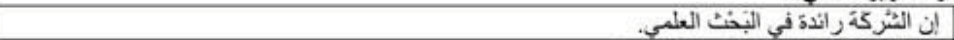 & 41 \\
\hline 543321 & 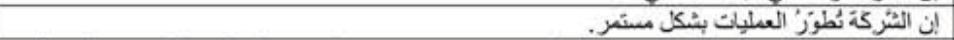 & 42 \\
\hline 54321 & 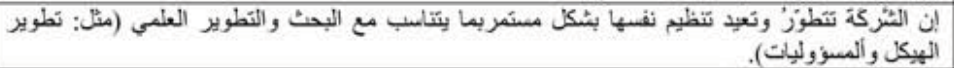 & 43 \\
\hline 54321 & 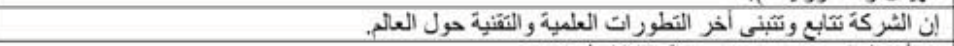 & 44 \\
\hline 543321 & 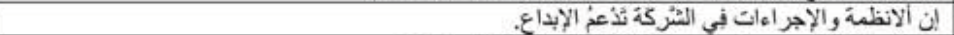 & 45 \\
\hline 54321 & 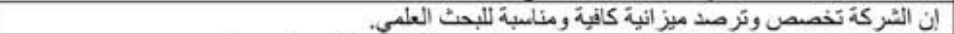 & 46 \\
\hline 54321 & 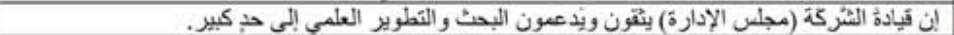 & 47 \\
\hline 543321 & 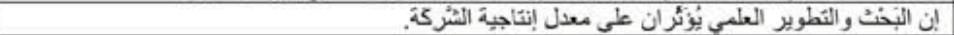 & 48 \\
\hline 54321 & 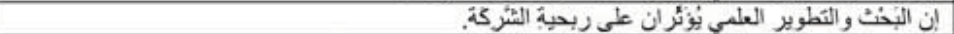 & 49 \\
\hline 54321 & 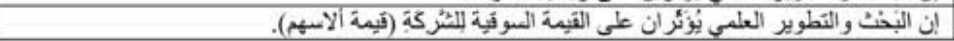 & 50 \\
\hline
\end{tabular}

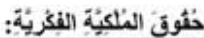

\begin{tabular}{|c|c|c|}
\hline 543221 & 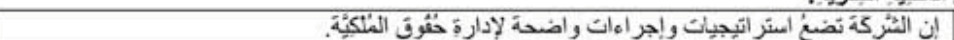 & 51 \\
\hline 54321 & 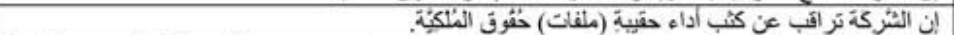 & 52 \\
\hline 543221 & 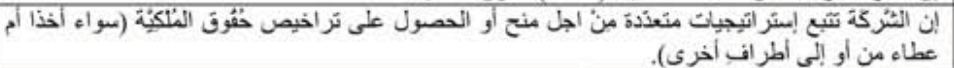 & 53 \\
\hline 543321 & 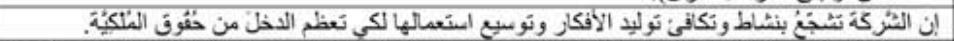 & 54 \\
\hline 54321 & 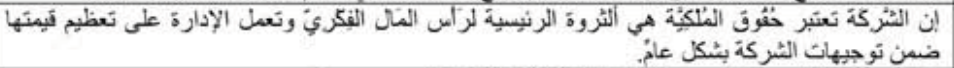 & 55 \\
\hline 544321 & 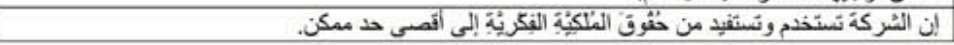 & 56 \\
\hline
\end{tabular}

(Continued)

Figure A2. 
$\mathrm{MD}$

48,1

\section{0}

\begin{tabular}{|c|c|c|}
\hline 54321 & 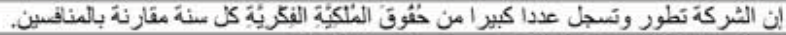 & 57 \\
\hline 543321 & 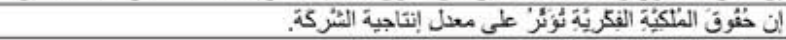 & 58 \\
\hline 544321 & 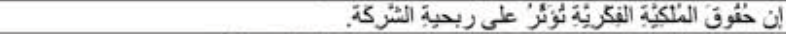 & 59 \\
\hline 54321 & 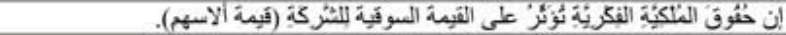 & 60 \\
\hline
\end{tabular}

رأس ألمل ألعلاقتاتي (ألزباتني)

التحالفات الإستر اتيجية و التُراخيص و الآتفاقيات:

\begin{tabular}{|c|c|c|}
\hline 54321 & 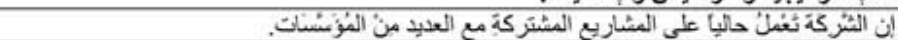 & 61 \\
\hline 54321 & 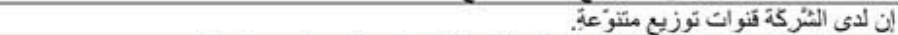 & 62 \\
\hline 543321 & 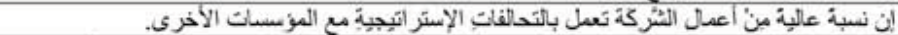 & 63 \\
\hline 54321 & 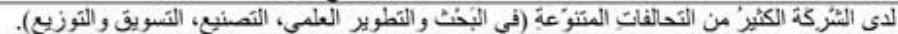 & 64 \\
\hline 54321 & 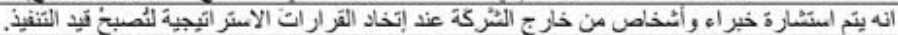 & 65 \\
\hline 54321 & 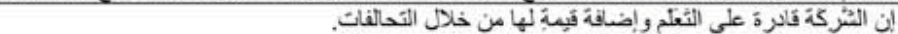 & 66 \\
\hline 54321 & 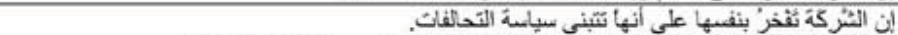 & 67 \\
\hline 54321 & 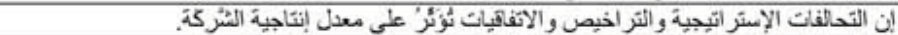 & 68 \\
\hline 54321 & 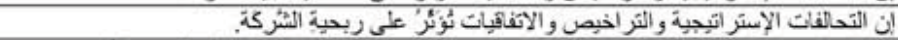 & 69 \\
\hline 543321 & 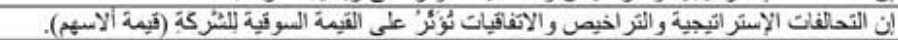 & 70 \\
\hline
\end{tabular}

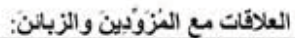

\begin{tabular}{|c|c|c|}
\hline 54321 & 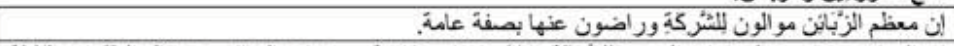 & 71 \\
\hline 54321 & 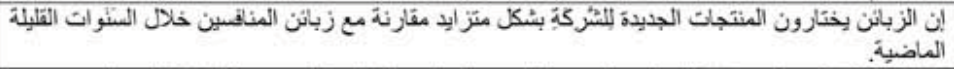 & 72 \\
\hline 54321 & 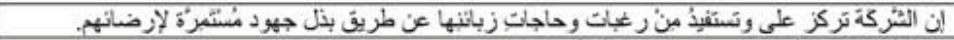 & 73 \\
\hline 54321 & 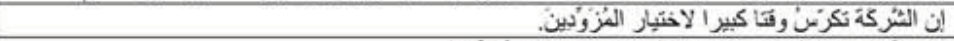 & 74 \\
\hline 543321 & 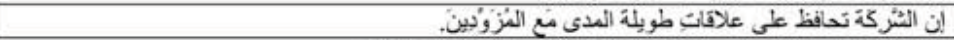 & 75 \\
\hline 54321 & 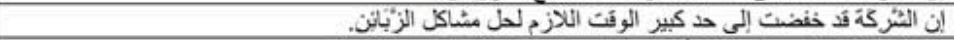 & 76 \\
\hline 543321 & 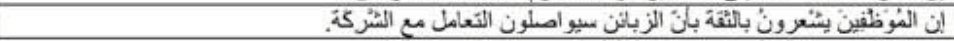 & 77 \\
\hline 54321 & 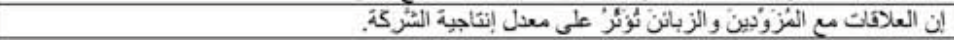 & 78 \\
\hline 54321 & 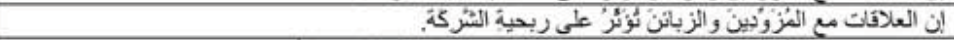 & 79 \\
\hline 543321 & 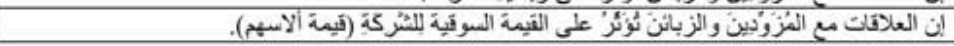 & 80 \\
\hline
\end{tabular}

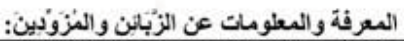

\begin{tabular}{|c|c|c|}
\hline 543321 & 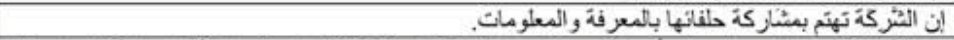 & 81 \\
\hline 543321 & 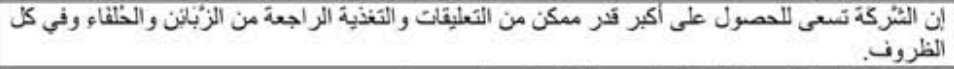 & 82 \\
\hline 544321 & 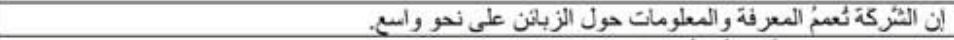 & 83 \\
\hline 54321 & 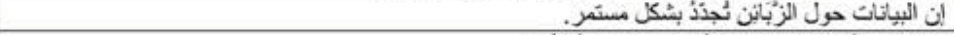 & 84 \\
\hline 54321 & إن لدى المثركة بياتات كاملة نمبياً حول المُزوِدين. & 85 \\
\hline 54321 & 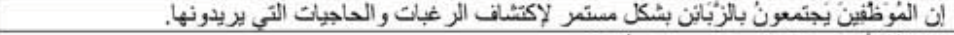 & 86 \\
\hline 54321 & إن نظام أمعلوماتِ المستخدم مفيد ومُحدتُ. & 87 \\
\hline 543321 & 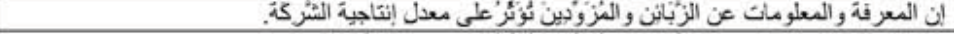 & 88 \\
\hline 543321 & 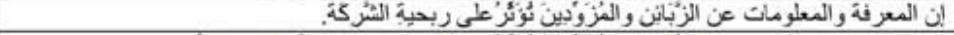 & 89 \\
\hline 54321 & 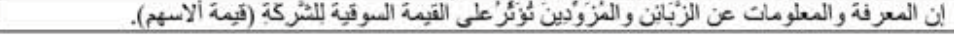 & 90 \\
\hline
\end{tabular}

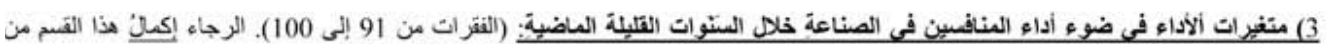

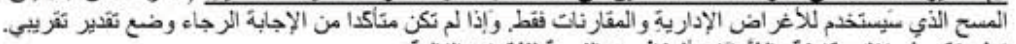

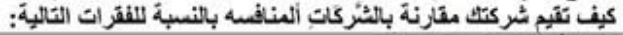

\begin{tabular}{|c|c|c|}
\hline 54321 & القِيلدة في الصناعة. & 91 \\
\hline 544321 & التطلعات المستقلبلية. & 92 \\
\hline 54321 & 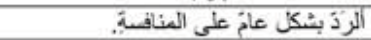 & 93 \\
\hline 543321 & نسبة النجاح في تسويق المثتجات الجديدة. & 94 \\
\hline 544321 & 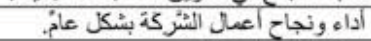 & 95 \\
\hline 544321 & معدل إنتاج الموظف. & 96 \\
\hline 544321 & معدل إنتاجِيَة العملية (الحركة). & 97 \\
\hline
\end{tabular}

(Continued)

Figure A2. 


\begin{tabular}{|c|c|c|}
\hline $5 \quad 443221$ & ئمو الأرباح. & 98 \\
\hline 544321 & نيو المبيعات. & 99 \\
\hline 544321 & 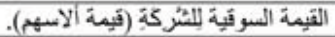 & 100 \\
\hline
\end{tabular}

IC and business
performance

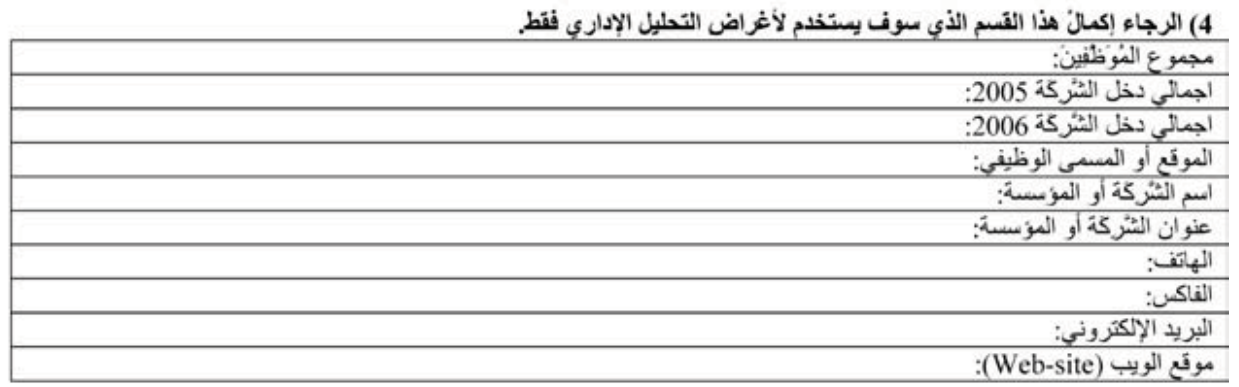

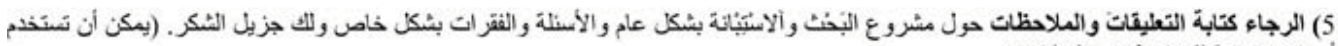

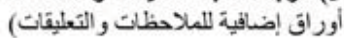

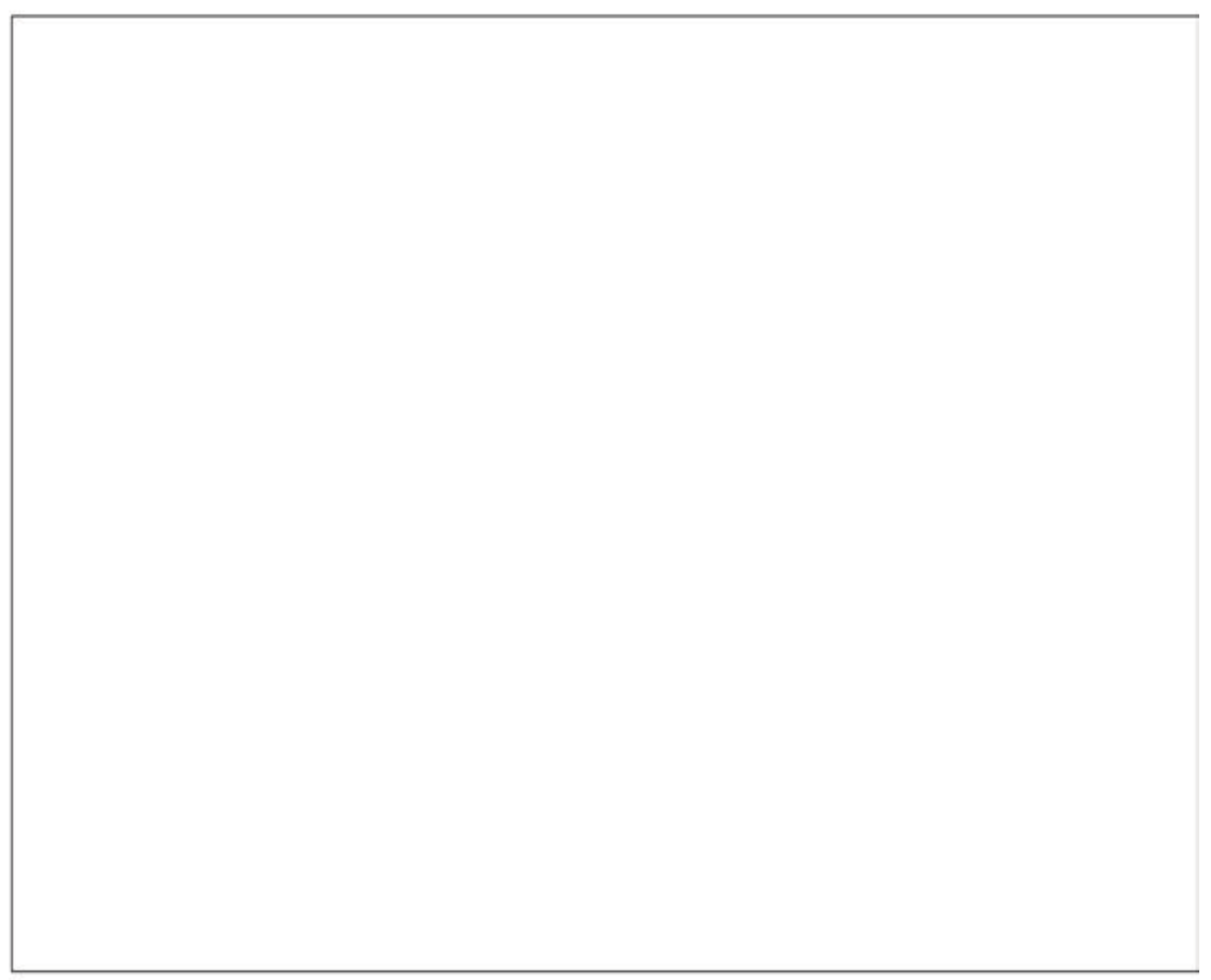

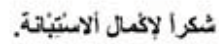

Figure A2.

عبدالعزيزأحمد ألثشرباتي.

Corresponding author

Abdel-Aziz Ahmad Sharabati can be contacted at: apharmaart@cyberia.jo

To purchase reprints of this article please e-mail: reprints@emeraldinsight.com Or visit our web site for further details: www.emeraldinsight.com/reprints 